\title{
Study of carbon dioxide electrochemical reduction in flow cell system using copper modified boron-doped diamond
}

\author{
Salsabila Zahran Ilyasa ${ }^{1}$, Prastika Krisma Jiwanti ${ }^{2}$, Munawar Khalil ${ }^{1}$, Yasuaki Einaga ${ }^{3}$ and \\ Tribidasari Anggraningrum Ivandini ${ }^{{ }^{*}}$ \\ ${ }^{1}$ Department of Chemistry, Faculty of Mathematics and Natural Sciences, Universitas Indonesia, \\ Depok, 16424, Indonesia \\ ${ }^{2}$ Nanotechnology Engineering, School of Advanced Technology and Multidisciplinary, Universitas \\ Airlangga, Surabaya, 60115, Indonesia \\ ${ }^{3}$ Department of Chemistry, Faculty of Science and Technology, Keio University, 3-14-1 Hiyoshi, \\ Yokohama, 223-8522, Japan
}

\begin{abstract}
High concentrations of $\mathrm{CO}_{2}$ in the atmosphere may cause climate and environmental changes. Therefore, various research has been extensively performed to reduce $\mathrm{CO}_{2}$ by converting $\mathrm{CO}_{2}$ directly into hydrocarbons. In this research, $\mathrm{CO}_{2}$ electrochemical reduction was studied using boron-doped diamond (BDD) modified with copper nanoparticles to improve BDD electrodes' catalytic properties. The deposition was performed by chronoamperometry technique at a potential of $-0.6 \mathrm{~V}$ (vs. $\mathrm{Ag} / \mathrm{AgCl}$ ) and characterized using SEM, EDS, XPS, and cyclic voltammetry $(\mathrm{CV}) . \mathrm{CO}_{2}$ electrochemical reduction on $\mathrm{BDD}$ and $\mathrm{Cu}-\mathrm{BDD}$ was carried out at $-1.5 \mathrm{~V}$ (vs. $\mathrm{Ag} / \mathrm{AgCl}$ ) for 60 minutes. The products were analyzed using HPLC and GC. The product was mainly formic acid with a concentration of $11.33 \mathrm{mg} / \mathrm{L}$ and $33 \%$ faradaic efficiency on a Cu-BDD electrode.
\end{abstract}

\section{Introduction}

High concentrations of $\mathrm{CO}_{2}$ in the atmosphere promotes climate change and severe effect on the environment. Therefore, various efforts were made to reduce the increase of $\mathrm{CO}_{2}$ gas emissions. Of the many techniques that have been examined, the electrochemical reduction is one of the most widely used [1-3]. Electrochemical is an effective method of converting $\mathrm{CO}_{2}$ into more valuable compounds due to several advantages such as applicative, simple, and selective on the product produced. The specifications of $\mathrm{CO}_{2}$ reduction products can be adjusted under various reaction conditions [4-7]. One of the factors that influence the variety of $\mathrm{CO}_{2}$ electrochemical reduction products is the type of electrodes used.

In this study, the boron-doped diamond (BDD) electrode is used as working electrodes because they have the advantages of a wide potential window, low background current, and high stability, making them chemically inert and mechanically reliable $[4,8]$. However, the

\footnotetext{
*Corresponding author: ivandini.tri@sci.ui.ac.id
} 
BDD electrode has disadvantages, namely relatively low catalytic activity, resulting in a high overpotential $\mathrm{CO}_{2}$ electrochemical reduction requirement. So, it is necessary to modify BDD to increase its catalytic activity.

BDD surface modification with metal particles is expected to increase the BDD electrode's catalytic effect and performance [9-13]. The metal particles deposited on the BDD surface act as the electrodes' active site to stabilize the reaction intermediate to lower the overpotential [14] and produce a more varied product compared to bare BDD. Previous studies reported that BDD surface modification with copper metal could improve BDD electrodes' catalytic activity and performance to produce various $\mathrm{CO}_{2}$ reduction products, especially hydrocarbons and oxygenated species [15-19]. Besides, a flow cell system in $\mathrm{CO}_{2}$ electrochemical reduction using BDD electrodes has been reported to improve the $\mathrm{CO}_{2}$ mass transport and produce formic acid as the main product with a faradaic efficiency of 94.7\% [20]. This study was conducted using $\mathrm{Cu}$-BDD electrodes with a flow cell system to achieve higher efficiency or suppress the overpotential. The characteristics of $\mathrm{Cu}-\mathrm{BDD}$ electrodes before and after $\mathrm{CO}_{2}$ reduction, the analysis of the resulting compounds, and the effect of using a flow cell system compared to a static system using the $\mathrm{Cu}$-BDD electrode will be presented in this report.

\section{Method}

\subsection{Materials}

$\mathrm{KCl}(>99.5 \%), \mathrm{KOH}(85 \%), \mathrm{CuSO}_{4} \cdot 5 \mathrm{H}_{2} \mathrm{O}(>99.5 \%), \mathrm{H}_{2} \mathrm{SO}_{4}(95 \%)$, and 2-propanol were purchased from Wako Pure Chemical Industries Ltd. and used without further purification. Ultra-pure water was obtained from a Symply-Lab water system (Direct-Q 3 UV, Millipore).

\subsection{Working electrodes preparation}

Boron-doped diamond electrodes were prepared on $\mathrm{Si}(100)$ wafers as substrates using a microwave plasma-assisted chemical vapor deposition system (AX 5400, Cornes Technologies Ltd.) following a procedure described elsewhere [21]. The boron-doped diamond (BDD) electrode modification was carried out by the electrodeposition method. This method uses a chronoamperometric technique with $1 \mathrm{mM} \mathrm{CuSO}_{4}$ in a $0.1 \mathrm{M} \mathrm{H}_{2} \mathrm{SO}_{4}$ solution. $\mathrm{Cu}$ deposition was carried out on the BDD working electrode in one compartment cell with $\mathrm{Ag} / \mathrm{AgCl}$ and $\mathrm{Pt}$ spiral as a reference and counter electrode, respectively. The electrodeposition was applied at a potential $-0.6 \mathrm{~V}$ for $25 \mathrm{~s}$ (Cu-BDD 25s), $50 \mathrm{~s}$ (Cu-BDD 50s), $100 \mathrm{~s}$ (Cu-BDD 100s), and $150 \mathrm{~s}$ (Cu-BDD 150s). Characterization of the electrodes was performed by Scanning Electron Microscopy (SEM) (JCM-600, JEOL), Energy Dispersive X-ray analysis (EDX), and X-Ray Photoelectron Spectroscopy (XPS) (JPS9010TR, JEOL).

\section{$2.3 \mathrm{CO}_{2}$ electrochemical reduction method}

The electrochemical cell used in $\mathrm{CO}_{2}$ electrolysis is a two-compartment PTFE flow cell separated by a Nafion membrane (Fig. 1). The working electrode was $\mathrm{Cu}-\mathrm{BDD}, \mathrm{Ag} / \mathrm{AgCl}$ as a reference electrode and a Pt plate as a counter electrode. The area of the working electrode is $9.62 \mathrm{~cm}^{2}$ [20]. The catholyte used was $0.5 \mathrm{M} \mathrm{KCl} 50 \mathrm{~mL}$, and the anolyte used was $0.1 \mathrm{M} \mathrm{KOH} 50 \mathrm{~mL}$. Before electrolysis, the catholyte was bubbled with $\mathrm{N}_{2}$ gas for 30 minutes, followed by $\mathrm{CO}_{2}$ gas bubbled for 15 minutes, both at a flow rate of $200 \mathrm{sccm}$. The 
$\mathrm{CO}_{2}$ reduction process was recorded using a potentiostat (Autolab PGSTAT204, Metrohm Autolab B.V.) for 1 hour and carried out at a potential of $-1.5 \mathrm{~V} . \mathrm{CO}_{2}$ gas at a low flow rate was flowed during the reduction process to maintain $\mathrm{CO}_{2}$ concentration in the flow cell system. Gas chromatography (GC-2014, Shimadzu Corp.) analyzed the gas products, and the liquid product was analyzed using high-performance liquid chromatography with an electroconductivity detector (Prominence, Shimadzu Corp.).

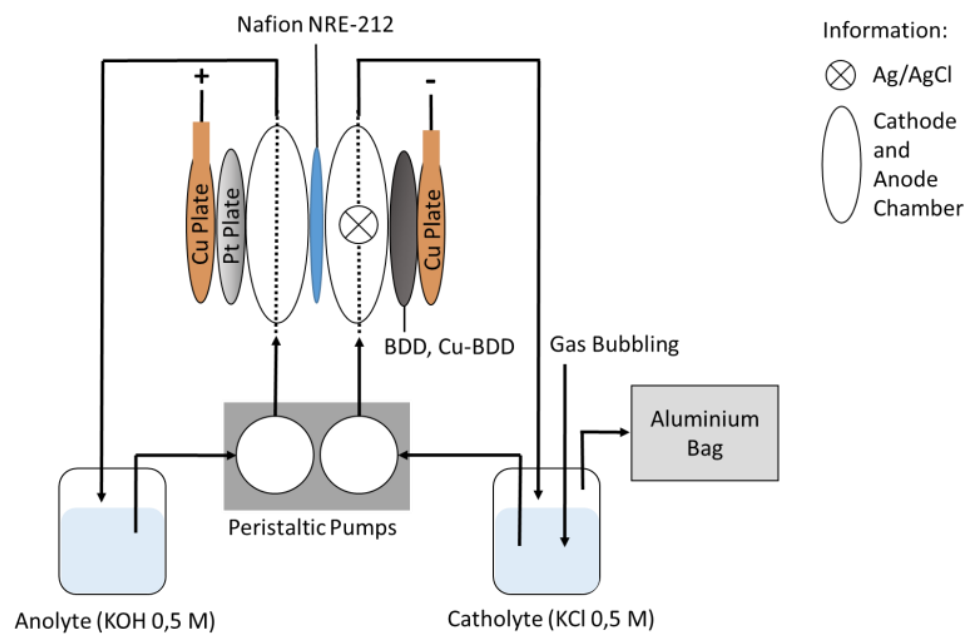

Fig. 1. Flow cell for electrochemical reduction.

\section{Results and discussion}

\subsection{Working electrodes characterization}

Cyclic voltammogram of $\mathrm{Cu}-\mathrm{BDD}$ electrodes at various deposition times was performed from $-0.8 \mathrm{~V}$ to $+0.8 \mathrm{~V}$ (vs. $\mathrm{Ag} / \mathrm{AgCl}$ ) with a scan rate of $100 \mathrm{mV} / \mathrm{s}$ (Fig. 2). $\mathrm{Cu}$ dissolution, following the various $\mathrm{Cu}$ phases deposited during the potential negative sweep, is indicated by peak currents at a positive potential. With the negative-going potential, the first reduction peak of $\mathrm{Cu}^{2+}$ to $\mathrm{Cu}^{+}$occurs at a potential of around $-0.19 \mathrm{~V},-0.19 \mathrm{~V},-0.15 \mathrm{~V}$, and $-0.25 \mathrm{~V}$ in $\mathrm{Cu}-\mathrm{BDD} 25 \mathrm{~s}, \mathrm{Cu}-\mathrm{BDD} 50 \mathrm{~s}, \mathrm{Cu}-\mathrm{BDD} 100 \mathrm{~s}$, and $\mathrm{Cu}-\mathrm{BDD} 150 \mathrm{~s}$, respectively. The reduction of $\mathrm{Cu}^{2+}$ to $\mathrm{Cu}^{0}$ contained a potential around $-0.34 \mathrm{~V},-0.40 \mathrm{~V},-0.25 \mathrm{~V}$, and $0.45 \mathrm{~V}$ in $\mathrm{Cu}-\mathrm{BDD} 25 \mathrm{~s}, \mathrm{Cu}-\mathrm{BDD}$ 50s, Cu-BDD 100s, and Cu-BDD 150s, respectively. This phase is indicating $\mathrm{Cu}$ deposition on the BDD electrodes surface. The steep drop in potential around $-0.60 \mathrm{~V}$ is due to hydrogen evolution, which causes a slight change in the BDD surface termination. Based on the CV data obtained, it shows that $\mathrm{Cu}-\mathrm{BDD} 100$ s has an advantage in reducing $\mathrm{Cu}$. The process of reducing $\mathrm{Cu}$ at a more positive potential in $\mathrm{Cu}$ deposited having a density and evenly distributed over the BDD surface [22]. 


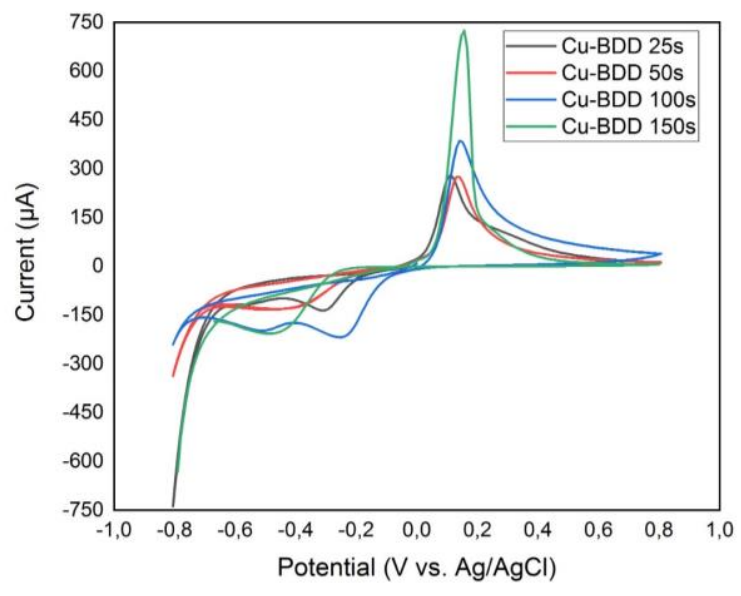

Fig. 2. Cyclic voltammogram of $\mathrm{Cu}-\mathrm{BDD}$ electrodes at various $\mathrm{Cu}$ deposition times.

SEM-EDX examined all the Cu-BDD electrodes after electrodeposition. Based on Fig. 3 (a) and (b), there is no visible deposition of Cu. In Fig. 3 (c), a white dot shows that the deposited $\mathrm{Cu}$ particles were evenly uniformly distributed on the BDD surface, with average particle sizes of around $\sim 148 \mathrm{~nm}$. In contrast, Fig. 3 (d) shows the $\mathrm{Cu}$ particles have agglomerated. Based on the SEM images, the $\mathrm{Cu}$-BDD 100s electrode showed significant characteristics compared to other deposition time variations. This case can be proven by EDX Spectroscopy, which can determine the atomic percentages on each electrode's surface, and the results are summarized in Table 1.
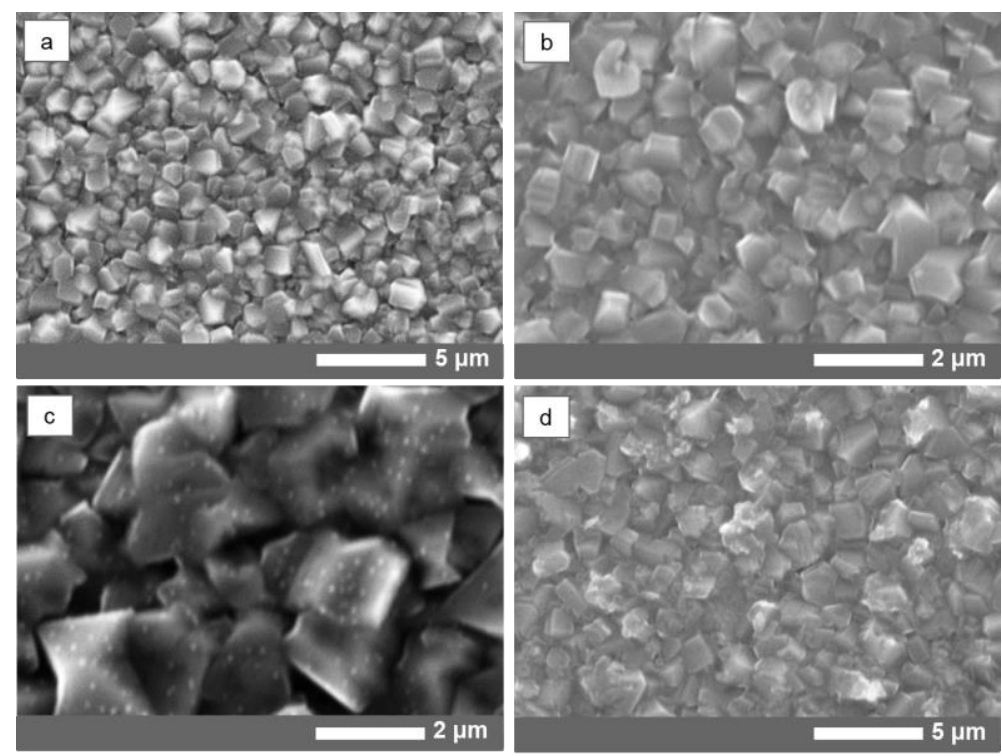

Fig. 3. SEM images of Cu-BDD electrodes with deposition times of $25 \mathrm{~s}$ (a), $50 \mathrm{~s}$ (b), $100 \mathrm{~s}$ (c), and 150 (d).

Moreover, the $\mathrm{Cu}$ particles on the electrode surfaces were also characterized using XPS. XPS spectra showed a pair of energy peaks at $933 \mathrm{eV}$ and $952.4 \mathrm{eV}$, which are representative of $\mathrm{Cu} 2 \mathrm{p}_{3 / 2}$ and $\mathrm{Cu} 2 \mathrm{p}_{1 / 2}$ binding energy in $\mathrm{Cu}^{0}$ for all $\mathrm{Cu}-\mathrm{BDD}$ variations. 
XPS also showed the \% mass of the $\mathrm{Cu}$-BDD electrodes, with the highest percentage being $\sim 13 \%$ belonging to $\mathrm{Cu}-\mathrm{BDD} 100 \mathrm{~s}$. Based on this, $\mathrm{Cu}-\mathrm{BDD} 100 \mathrm{~s}$ was used as an electrode for $\mathrm{CO}_{2}$ electrochemical reduction.

Table 1. Mass percentage of each deposited material.

\begin{tabular}{ccccc}
\hline \multirow{2}{*}{ Element } & \multicolumn{4}{c}{ \% Mass } \\
\cline { 2 - 5 } & Cu-BDD 25s & Cu-BDD 50s & Cu-BDD 100s & Cu-BDD 150s \\
\hline $\mathrm{C}$ & 99.96 & 99.67 & 99.10 & 99.11 \\
$\mathrm{O}$ & 0.04 & 0.02 & 0.07 & 0.11 \\
$\mathrm{Cu}$ & 0 & 0.02 & 0.83 & 0.78 \\
\hline
\end{tabular}

\section{$3.2 \mathrm{CO}_{2}$ electrochemical reduction}

$\mathrm{CO}_{2}$ electrochemical reduction was carried out for 1 hour using the $\mathrm{Cu}-\mathrm{BD} 100$ s electrode at $-1.5 \mathrm{~V}$ potential. After the $\mathrm{CO}_{2}$ electrochemical reduction reaction was done, the $\mathrm{Cu}-$ BDD 100s electrode was characterized using SEM-EDS to see their performance after being used in $\mathrm{CO}_{2}$ electrochemical reduction. SEM images in Fig. 4 show significant differences in the $\mathrm{Cu}-\mathrm{BDD} 100 \mathrm{~s}$ surface before and after $\mathrm{CO}_{2}$ electrochemical reduction, indicating that the deposited $\mathrm{Cu}$ particles were detached from the surface of the BDD surface. The change in the mass $\%$ of the $\mathrm{Cu}$-BDD electrode element decreased the mass\% of $\mathrm{Cu}$ by $97.59 \%$. This decrease happens both before and after the analysis of $\mathrm{CO} 2$ reduction using EDS.
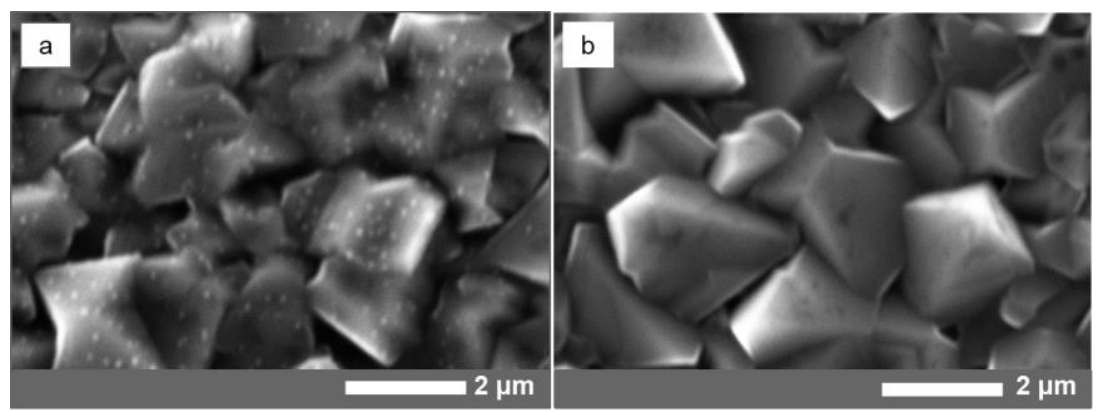

Fig. 4. SEM Images of $\mathrm{Cu}-\mathrm{BDD} 100 \mathrm{~s}$ (a) before and (b) after $\mathrm{CO}_{2}$ electrochemical reduction.

The produces products were analyzed using HPLC and GC instrumentation. Fig. 5 shows the efficiencies with which formic acid, carbon monoxide, methane, and hydrogen gas were produced by using $\mathrm{Cu}-\mathrm{BDD} 100 \mathrm{~s}$ electrode at $-1.5 \mathrm{~V}$ potential for 1 hour. The highest faradaic efficiency was achieved for formic acid, carbon monoxide, methane, and hydrogen gas, $33 \%, 1.67 \%, 0.05 \%$, and $21.25 \%$. Furthermore, the $\mathrm{CO}_{2}$ electrochemical reduction using bare BDD electrodes was carried out in the same experimental system to compare the product. On the bare BDD electrode, formic acid, carbon monoxide, or hydrogen gas were observed on the Cu-BDD 100s electrode. The highest faradaic efficiency was achieved for formic acid, carbon monoxide, and hydrogen gas, $14.69 \%$, $12.96 \%$, and $49.57 \%$. In conclusion, $\mathrm{Cu}-\mathrm{BDD} 100 \mathrm{~s}$ and bare BDD electrodes show insignificant differences in the produce products. 


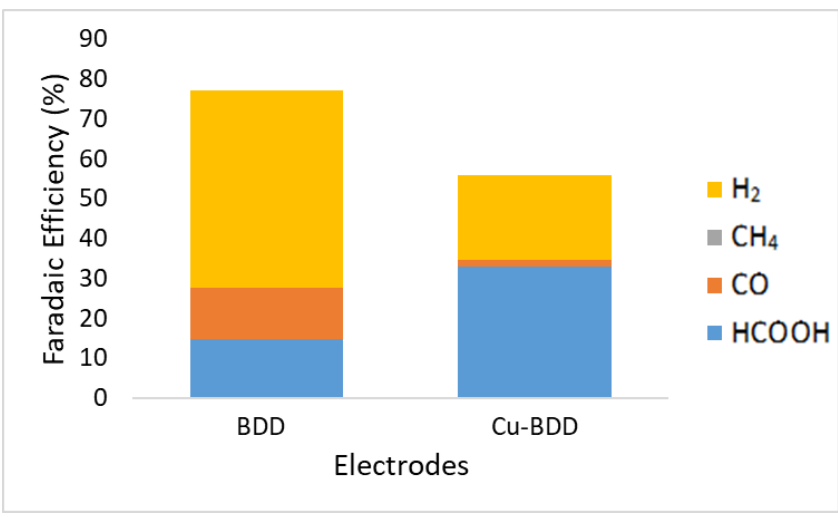

Fig. 5. Product produced by the electrochemical reduction of $\mathrm{CO}_{2}$ on a bare BDD and $\mathrm{Cu}-$ BDD 100s electrodes at potential $-1.5 \mathrm{~V}$ for $1 \mathrm{~h}$.

Table 2 shows the concentration and the faradaic efficiency of the product's reduction process on bare $\mathrm{BDD}$ or $\mathrm{Cu}-\mathrm{BDD}$ electrodes. In this study, the main product was formic acid because diamonds tend to produce formic acid [20]. The $\mathrm{Cu}$-BDD electrode has a more remarkable ability than the bare BDD electrode in producing formic acid. This ability can be seen from the resulting faraday efficiency, which is $14.69 \%$ and $33 \%$ in BDD and $\mathrm{Cu}-$ BDD electrodes, respectively.

Table 2. The concentration and faradaic efficiency of $\mathrm{CO}_{2}$ reduction products

\begin{tabular}{ccccc}
\hline \multirow{2}{*}{ Products } & \multicolumn{2}{c}{ Concentration $(\mathbf{m g} / \mathbf{L})$} & \multicolumn{2}{c}{ Faradaic Efficiency $(\%)$} \\
\cline { 2 - 5 } & BDD & Cu-BDD & BDD & Cu-BDD \\
\hline $\mathrm{HCOOH}$ & 2.59 & 11.33 & 14.69 & 33.00 \\
$\mathrm{CO}$ & 0.05 & 0.01 & 12.96 & 1.67 \\
$\mathrm{CH}_{4}$ & 0 & $9.05 \times 10^{-5}$ & 0 & 0.05 \\
$\mathrm{H}_{2}$ & 0.17 & 0.14 & 49.57 & 21.25 \\
\hline
\end{tabular}

The use of $\mathrm{Cu}$ metal in reducing $\mathrm{CO}_{2}$ tends to produce products in hydrocarbons, aldehydes, and alcohol. However, based on the reduction data, no aldehyde or alcohol products were formed because the use of flow cells affects the electrodes' ability to bind the intermediates produced $\left(\mathrm{CO}_{2}{ }^{-}\right)$[3]. The use of $\mathrm{Cu}$-BDD electrodes in flow cells and dormant cells [17] has differences in reduction. $\mathrm{CO}_{2}$ reduction reaction with $\mathrm{Cu}-\mathrm{BDD}$ using a flow cell produces methane gas, while the static cell produces methanol. Static cells tend to produce $\mathrm{C}_{2} / \mathrm{C}_{3}$ products, while flow cells cannot because the use of flow cells makes electrolytes or reactants hit the electrodes' surface more often so that no intermediate products are formed.

\section{Conclusion}

The use of $\mathrm{Cu}$ metal in reducing $\mathrm{CO}_{2}$ tends to produce products in hydrocarbons, aldehydes, and alcohol. However, based on the reduction data, no aldehyde or alcohol products were formed because the use of flow cells affects the electrodes' ability to bind the intermediates produced $\left(\mathrm{CO}_{2}{ }^{-}\right)$[3]. The use of $\mathrm{Cu}$-BDD electrodes in flow cells and dormant cells [17] has differences in reduction. $\mathrm{CO}_{2}$ reduction reaction with $\mathrm{Cu}-\mathrm{BDD}$ using a flow cell produces methane gas, while the static cell produces methanol. Static cells tend to produce $\mathrm{C}_{2} / \mathrm{C}_{3}$ products, while flow cells cannot because the use of flow cells makes 
electrolytes or reactants hit the electrodes' surface more often so that no intermediate products are formed.

\section{Acknowledgement}

The authors sincerely thank the financial support from Directorate Research and Development (Risbang), Universitas Indonesia for the Hibah PUTI Kolaborasi Internasional 2020 No. NKB-777/UN2.RST/HKP.05.00/2020 granted.

\section{References}

1. P.K. Jiwanti, Y. Einaga, Electrochemical reduction of $\mathrm{CO} 2$ using palladium modified boron-doped diamond electrodes: Enhancing the production of CO, Physical Chemistry Chemical Physic, 21, 15297 (2019) https://doi.org/10.1039/C9CP01409H

2. Q. Lu, J. Feng, Electrochemical CO2 reduction: electrocatalyst, reaction mechanism, and process engineering, Nano Energy 29, 439 (2016)

https://doi.org/10.1016/j.nanoen.2016.04.009

3. D. D. Zhu, J. L. Liu, S. Z. Qiao, Recent advances in inorganic heterogeneous electrocatalysts for reduction of carbon dioxide, Adv. Mater. 28, 3423 (2016) https://doi.org/10.1002/adma.201504766

4. K. Nakata, T. Ozaki, C. Terashima, A. Fujishima, Y. Einaga, High-yield electrochemical production of formaldehyde from $\mathrm{CO}_{2}$ and seawater, Angewandte Chemie International Edition 53, 871 (2014) https://doi.org/10.1002/anie.201308657

5. H. Li et al., Integrated electromicrobial conversion of $\mathrm{CO}_{2}$ to higher alcohols, Science 335, 1596 (2012) https://doi.org/10.1126/science.1217643

6. B. A. Rosen et al., Ionic liquid-mediated selective conversion of $\mathrm{CO} 2$ to $\mathrm{CO}$ at low overpotentials, Science 334, 644 (2011) https://www.doi.org/10.1126/science.1209786

7. R. Angamuthu, P. Byers, M. Lutz, A. L. Spek, E. Bouwman, Electrocatalytic $\mathrm{CO}_{2}$ conversion to oxalate by a copper complex, Science 327, 313 (2010) https://www.doi.org/10.1126/science.1177981

8. T. A. Ivandini, Y. Einaga, Diamond Electrochemistry (Elsevier Inc., 2017)

9. S. Muharam, P. K. Jiwanti, Irkham, J. Gunlazuardi, Y. Einaga, T. A. Ivandini, Electrochemical oxidation of palmitic acid solution using boron-doped diamond electrodes, Diamond and Related Materials 99, 107464 (2019) https://doi.org/10.1016/j.diamond.2019.107464

10. P. K. Jiwanti, A. M. Ichzan, R. K. P. Dewandaru, S. R. Atriardi, Y. Einaga, T. A. Ivandini, Improving the $\mathrm{CO} 2$ electrochemical reduction to formic acid using iridiumoxide-modified boron-doped diamond electrodes, Diamond and Related Materials 106, 107874 (2020) https://doi.org/10.1016/j.diamond.2020.107874

11. P. K. Jiwanti, R. P. Aritonang, I. Abdullah, Y. Einaga, T. A. Ivandini, Copper-nickelmodified Boron-doped Diamond Electrode for $\mathrm{CO}_{2}$ electrochemical reduction application: a preliminary study, Makara Journal of Science. 23, 204 (2019) https://doi.org/10.7454/mss.v23i4.11512

12. T. Agustiany, M. Khalil, Y. Einaga, P. K. Jiwanti, T. A. Ivandini, Stable iridiummodified boron-doped diamond electrode for the application in electrochemical detection of arsenic (III), Materials Chemistry and Physics 244, 1 (2020) https://www.doi.org/10.1016/j.matchemphys.2020.122723

13. S. R. Atriardi, Preparation of boron-doped diamond modified platinum-iridium for electrochemical reduction of carbon dioxide $\left(\mathrm{CO}_{2}\right)$, Theses. Universitas Indonesia, (2017) 
14. S. Ma et al., Electroreduction of carbon dioxide to hydrocarbons using bimetallic $\mathrm{Cu}$ Pd catalysts with different mixing patterns, Journal of the American Chemical Society, 139, 47 (2017) https://doi.org/10.1021/jacs.6b10740

15. K. P. Kuhl, E. R. Cave, D. N. Abram, T. F. Jaramillo, New insights into the electrochemical reduction of carbon dioxide on metallic copper surfaces, Energy \& Environmental Science, 5, 7050 (2012) https://doi.org/10.1039/C2EE21234J

16. H. S. Panglipur, Electroreduction of $\mathrm{CO}_{2}$ using copper-deposited on boron-doped diamond (BDD), AIP Conference Proceedings 1729, 20 (2015) https://doi.org/10.1063/1.4946950

17. P. K. Jiwanti, K. Natsui, K. Nakata, Y. Einaga, The electrochemical production of $\mathrm{C} 2 / \mathrm{C} 3$ species from carbon dioxide on copper-modified boron-doped diamond electrodes, Electrochimica Acta, 266, 414 (2018) https://doi.org/10.1016/j.electacta.2018.02.041

18. N. Roy et al., Facile deposition of $\mathrm{Cu}-\mathrm{SnOx}$ Hybrid Nanostructures on lightly BoronDoped Diamond Electrodes for $\mathrm{CO}_{2}$ reduction, ChemElectroChem 5, 2542 (2018) https://doi.org/10.1002/celc. 201800460

19. N. Roy et al., Ionic-liquid-assisted selective and controlled electrochemical $\mathrm{CO}_{2}$ reduction at $\mathrm{Cu}-$ Modified Boron-Doped Diamond electrode, ChemElectroChem 3, 1044 (2016) https://doi.org/10.1002/celc.201600105

20. K. Natsui, H. Iwakawa, N. Ikemiya, K. Nakata, Y. Einaga, Stable and highly efficient electrochemical production of formic acid from carbon dioxide using diamond electrodes, Angewandte Chemie International Edition 57, 2639 (2018) https://doi.org/10.1002/anie.201712271

21. K. Natsui, C. Yamaguchi, Y. Einaga, Recovery of copper from dilute cupric sulfate solution by electrodeposition method using boron-doped diamond electrodes, Physica Status Solidi (A) Applications and Materials Science 213, 2081 (2016) https://doi.org/10.1002/pssa.201600159

22. A. B. Couto, M. C. E. Ribeiro, F. L. Migliorini, N. G. Ferreira, and M. R. Baldan, A comparative study of copper electrodeposition and photoelectrodeposition on boron doped diamond, Diamond and Related Materials 38, 104 (2013) https://doi.org/10.1016/j.diamond.2013.06.009 